\title{
Laser-induced breakdown spectroscopy-based geochemical fingerprinting for the rapid analysis and discrimination of minerals: the example of garnet
}

\author{
Daniel C. Alvey, ${ }^{1}$ Kenneth Morton, ${ }^{2}$ Russell S. Harmon, ${ }^{3, \star}$ Jennifer L. Gottfried, ${ }^{4}$ \\ Jeremiah J. Remus, ${ }^{2}$ Leslie M. Collins, ${ }^{2}$ and Michael A. Wise ${ }^{5}$ \\ 'U.S. Military Academy, West Point, New York 10996 USA \\ ${ }^{2}$ Department of Electrical and Computer Engineering, Duke University, Durham, North Carolina 27708 USA \\ ${ }^{3}$ U.S. Army Research Laboratory, Army Research Office, Durham, North Carolina 27703, USA \\ ${ }^{4}$ U.S. Army Research Laboratory, Aberdeen Proving Ground, Maryland 21005, USA \\ ${ }^{5}$ Department of Mineral Sciences, Smithsonian Institution, Washington, District of Columbia 20013 USA \\ ${ }^{*}$ Corresponding author: russell.harmon@ us.army.mil
}

Received 28 September 2009; accepted 18 December 2009;

posted 4 March 2010 (Doc. ID 117767); published 19 March 2010

\begin{abstract}
Laser-induced breakdown spectroscopy (LIBS) is an analytical technique real-time geochemical analysis that is being developed for portable use outside of the laboratory. In this study, statistical signal processing and classification techniques were applied to single-shot, broadband LIBS spectra, comprising measured plasma light intensities between 200 and $960 \mathrm{~nm}$, for a suite of 157 garnets of different composition from 92 locations worldwide. Partial least squares discriminant analysis was applied to sets of 25 LIBS spectra for each garnet sample and used to classify the garnet samples based on composition and geographic origin. Careful consideration was given to the cross-validation procedure to ensure that the classification algorithm is robust to unseen data. The results indicate that broadband LIBS analysis can be used to discriminate garnets of different composition and has the potential to discern geographic origin. (C) 2010

OCIS codes: $140.3440,300.6365$.
\end{abstract}

\section{Introduction}

Laser-induced spectroscopy (LIBS) is an analytical technique that has the potential for geochemical analysis in the field in real time. Since the technique is simultaneously sensitive to all elements, a single laser shot can be used to record the broadband LIBS emission spectra, which provides a unique chemical "fingerprint" of any material-solid, liquid, or gas. This study is a contribution to a long-term effort to examine the potential of using LIBS for geological

0003-6935/10/13C168-13\$15.00/0

(C) 2010 material discrimination. It builds directly on the work undertaken in the Army Research Laboratory spectroscopy laboratory since 2004 [1-7] that has been directed toward exploiting the unique potential that LIBS has for real-time geochemical "fingerprinting." For example, the ability to identify the geographic source area of gem minerals is one way of determining if a stone may have originated from a politically unstable area. This application of LIBS to natural geological materials focuses on using multivariate statistical classification techniques for the identification of different varieties of garnet, a semiprecious silicate mineral of highly variable composition that has been used as a gemstone since the 
Bronze Age. The study had two objectives: (i) to determine if the six basic garnet compositional species could be readily distinguished by LIBS and, if this was possible, (ii) to investigate whether it might be possible to use LIBS as a means of determining garnet provenance.

\section{Mineral Garnet}

Nesosilicate minerals are those in which the basic $\mathrm{SiO}_{4}$ tetrahedra building blocks are isolated and bound to each other only by ionic bonds from interstitial cations. Garnets comprise a complex group of nesosilicate minerals that crystallize as rhombic dodecahedrons, trapezohedrons, or a mixture of these two forms [Fig. 1(a)] and have a widely varying composition represented by the general formula $\mathrm{A}_{3} \mathrm{~B}_{2}\left(\mathrm{SiO}_{4}\right)_{3}$, where "A" and " $\mathrm{B}$ " refer, respectively, to cation sites of eightfold and sixfold coordination [8]. The "A" sites are occupied by large divalent cations, whereas the "B" sites host smaller trivalent cations [Fig. 1(b)]. Members of the garnet mineral group have the same cubic crystal structure, but may vary in chemical composition and, therefore, also exhibit ranges in many of their physical properties $[9,10]$.

Garnets occur in many different igneous and metamorphic geologic settings, which typically determines the particular type of garnet(s) present. The six common species of garnet form ideal end-member chemical compositions of isomorphous series [8]. As a consequence of cation size considerations in filling the " $\mathrm{A}$ " site, there is a division of garnets into those in which it contains $\mathrm{Ca}$ and those in which it is occupied by another divalent cation (e.g., $\mathrm{Mg}^{2+}, \mathrm{Fe}^{2+}$, or $\mathrm{Mn}^{2+}$ ). Thus, garnet can be divided into two broad compositional classes [11]: the ugrandite group consisting of end-member compositions with $\mathrm{Ca}^{2+}$ in the "A" site-andradite $\left[\mathrm{Ca}_{3} \mathrm{Fe}_{2}\left(\mathrm{SiO}_{4}\right)_{3}\right]$, grossular $\left[\mathrm{Ca}_{3} \mathrm{Al}_{2}\left(\mathrm{SiO}_{4}\right)_{3}\right]$, and uvarovite $\left[\mathrm{Ca}_{3} \mathrm{Cr}_{2}\left(\mathrm{SiO}_{4}\right)_{3}\right]$,

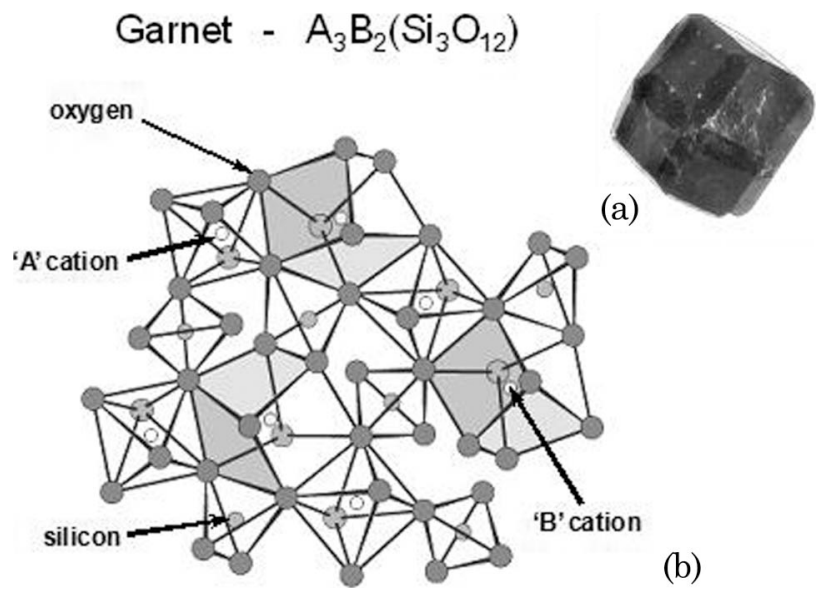

Fig. 1. (a) Natural garnet exhibiting mixed rhombic dodecahedron and trapezohedron crystal forms. Credit: Miller Museum of Geology and Mineralogy, Queens University. (b) Crystal structure of garnet, $\mathrm{A}_{3} \mathrm{~B}_{2} \mathrm{Si}_{3} \mathrm{O}_{12}$, comprised of distorted $\mathrm{SiO}_{4}$ tetraheda, $\mathrm{AO}_{8}$ polyhedra ("A" typically is $\mathrm{Ca}^{2+}, \mathrm{Mg}^{2+}, \mathrm{Fe}^{2+}$, or $\mathrm{Mn}^{2+}$ ) and $\mathrm{BO}_{6}$ octahedra ("B" is usually $\mathrm{Al}^{3+}$ but also can be $\mathrm{Fe}^{3+}$ or $\mathrm{Cr}^{3+}$ ). Modified from: http://www.britannica.com. whereas the end-member compositions almandine $\left[\mathrm{Fe}_{3} \mathrm{Al}_{2}\left(\mathrm{SiO}_{4}\right)_{3}\right]$, pyrope $\left[\mathrm{Mg}_{3} \mathrm{Al}_{2}\left(\mathrm{SiO}_{4}\right)_{3}\right]$, and spessartine $\left[\mathrm{Mn}_{3} \mathrm{Al}_{2}\left(\mathrm{SiO}_{4}\right)_{3}\right]$ comprise the pyralspite group, which has $\mathrm{Al}^{3+}$ in the "B" site [12]. Six other minor species of garnet occur in nature [8], but are not common and, therefore, were not considered in this study. It is important to note that garnets very rarely, if ever, occur in nature with compositions precisely matching the pure end-member species, so that names are assigned based on the dominant molecular type [8]. Because of similarity in ionic radius, "A"-site interchangeability of $\mathrm{Mg}^{2+}, \mathrm{Fe}^{2+}$, and $\mathrm{Mn}^{2+}$, solid solution is common within the ternary mixture of pyrope, almandine, and spessartine $[13,14]$ and also has been demonstrated between the ugranditepyralspite groups, both in the laboratory and in natural occurrence $[15,16]$. Chemical zoning is common but not universal, in garnets from metamorphic rocks, with compositional variation greatest near the margin of the mineral due to diffusion-reaction processes [17-20].

As would be expected from a chemically complex group of minerals, garnets owe their color to a variety of causes and can occur in all colors, including an exceptionally rare, blue color-change variety of pyropespessartine [21]. Garnet is allochromatic, meaning that most of the color variations in different garnets are due to their highly variable trace element impurities rather than to the elements that define their bulk composition. The color seen for a mineral is produced when light is selectively absorbed by ions or by interactions between ions. For example, absorption by $\mathrm{Cr}^{3+}, \mathrm{V}^{3+}, \mathrm{Fe}^{3+}$ (in the 6-coordinated site), $\mathrm{Fe}^{2+}$ (in the 8-coordinated site), or $\mathrm{Mn}^{2+}-\mathrm{Ti}^{4+}$, and $\mathrm{Fe}^{2+}-$ $\mathrm{Ti}^{4+}$ intervalence charge transfer can all be found in the visible spectra of garnets $[22,23]$. Different types of garnet can have the same color and, therefore, attempting to discriminate on the basis of color was not a consideration in this LIBS study, although it is the most common basis for classifying garnets when a chemical analysis is not available, particularly for commercial purposes.

\section{Experimental Methods}

A commercial bench-top laser-induced breakdown spectroscopy (LIBS) system from Ocean Optics (LIBS-SC) in routine operation at the Army Research Laboratory was used to analyze 157 garnet samples from 92 different locations worldwide (Table 1). The sample suite, which is a combination of garnets from the mineral collection of the Smithsonian Institution and garnets acquired specifically for this study, consisted of 26 almandines, 19 pyropes, 28 spessartines, 37 andradites, 32 grossulars, 10 uvarovites, 3 mixedtype samples, and 2 samples of unknown type. Because chemical analyses were not available for all samples, the classifications provided in the documentation accompanying the samples were accepted for purposes of this study. Small pieces a few $\mathrm{mm}$ in maximum dimension were taken from each garnet specimen and mounted in epoxy-filled Bakelite disks 


\begin{tabular}{|c|c|c|c|}
\hline \multicolumn{4}{|c|}{ GARNET SAMPLES } \\
\hline S.I. \# & Spec \# & Location & Country \\
\hline \multicolumn{4}{|l|}{ Andradite } \\
\hline & 24 & Mitchell County, NC & USA \\
\hline & 31 & Osgood Mountains, Humboldt County, NV & USA \\
\hline & 35 & Nchwaning Mine, Kuruman & South Africa \\
\hline & 36 & Trantimou, Cercle de Bafoulabe, Kayes Region & Mali \\
\hline & 64 & Asbestos, Quebec & Canada \\
\hline & 65 & Kirman & Iran \\
\hline & 67 & Sarbayskiy Mine, & Kazahkstan \\
\hline & 71 & not known & Kazahkstan \\
\hline & 69 & not known & Mali \\
\hline 16321 & 102 & Ural Mountains & Russia \\
\hline 107260 & 103 & Snohomish, WA & USA \\
\hline 106348 & 104 & Loudon County, VA & USA \\
\hline $47358-1$ & 105 & Burnet County, TX & USA \\
\hline 47358 & 106 & Burnet County, TX & USA \\
\hline B19470 & 107 & Zermatt & Switzerland \\
\hline 113829 & 108 & Zermatt & Switzerland \\
\hline $107258-1$ & 109 & Zermatt & Switzerland \\
\hline 107258 & 110 & Zermatt & Switzerland \\
\hline $\mathrm{C} 2744$ & 111 & Banat & Romania \\
\hline $107251-2$ & 113 & Banat & Romania \\
\hline B19492 & 115 & Banat & Romania \\
\hline R3469 & 117 & Franklin, NJ & USA \\
\hline R3467 & 120 & Franklin, NJ & USA \\
\hline 95204 & 122 & Franklin, NJ & USA \\
\hline $\mathrm{C} 6771$ & 124 & Franklin, NJ & USA \\
\hline 173775 & 125 & Eronogo & Namibia \\
\hline $107232-1$ & 126 & Pershing County, NY & USA \\
\hline 171064 & 129 & Chihuahua & Mexico \\
\hline R17196 & 130 & Chihuahua & Mexico \\
\hline $\mathrm{C} 2763$ & 132 & Carroll County, NH & USA \\
\hline B19638 & 133 & Lombardy & Italy \\
\hline 126160 & 134 & Lombardy & Italy \\
\hline 116725 & 135 & Lombardy & Italy \\
\hline 146475 & 137 & Piedmont & Italy \\
\hline $\mathrm{B} 19516$ & 139 & Vesuvio & Italy \\
\hline $\mathrm{R} 4284$ & 144 & Choto Nagur & India \\
\hline \multirow[t]{18}{*}{124835} & 147 & Prince of Wales Island, AK & USA \\
\hline & 15 & Aosta Valley & Italy \\
\hline & 20 & Bishop, Inyo County, CA & USA \\
\hline & 25 & Ducktown, TN & USA \\
\hline & 29 & Nioro do Sahel, Kayes Region & Mali \\
\hline & 33 & Coyote Front Range, Bishop, Inyo County, CA & USA \\
\hline & 34 & Cerro El Toro, Alamos, Sonora & Mexico \\
\hline & 37 & Jeffery Quarry, Asbestos,Quebec & Canada \\
\hline & 46 & Viluy River, Yakutia, Sakha, Siberia & Russia \\
\hline & 48 & Tumiq Tal, Gilgit & Pakistan \\
\hline & 49 & Sierra de las Cruces, Coahuila & Mexico \\
\hline & 50 & Havilah, Kern County, CA & USA \\
\hline & 51 & Sierra de las Cruces, Coahuila & Mexico \\
\hline & 52 & Sierra de las Cruces, Coahuila & Mexico \\
\hline & 58 & Sierra de las Cruces, Coahuila & Mexico \\
\hline & 61 & Akhtaragda River, Yakutia & Russia \\
\hline & 54 & Erongo & Namibia \\
\hline & 70 & Gejiu, Yunnan & China \\
\hline 139717 & 182 & Oxford, Quebec & Canada \\
\hline $\mathrm{R} 11362$ & 183 & Thetford Mines, Quebec & Canada \\
\hline 153479 & 184 & Jeffrey Mine, Asbestos, Shipton Township, Quebec & Canada \\
\hline $\mathrm{R} 18145$ & 185 & Asbestos, Shipton Township, Quebec & Canada \\
\hline 145817 & 186 & Jeffrey Mine, Asbestos, Shipton Township, Quebec & Canada \\
\hline 159513 & 187 & Asbestos, Shipton Township, Quebec & Canada \\
\hline 103111 & 188 & not known & Russia \\
\hline 144275 & 189 & not known & Tanzania \\
\hline
\end{tabular}




\begin{tabular}{|c|c|c|c|}
\hline \multicolumn{4}{|c|}{$\begin{array}{l}\text { Table 1. (Continued) } \\
\text { GARNET SAMPLES }\end{array}$} \\
\hline S.I. \# & Spec \# & Location & Country \\
\hline 143887 & 190 & Moshi & Tanzania \\
\hline 147797 & 191 & Oaxaca & Mexico \\
\hline 171584 & 192 & Coahuila & Mexico \\
\hline R7586-1 & 193 & Chihuahua & Mexico \\
\hline R19868 & 194 & Beaver County, UT & USA \\
\hline 132506 & 195 & Eden Mills, VT & USA \\
\hline 117637 & 196 & Eden Mills, VT & USA \\
\hline \multicolumn{3}{|l|}{ Uvarovite } & Canada \\
\hline & 28 & Mt. Saranovskaya, Ural Mountains & Russia \\
\hline & 42 & Sarany Mine, Ural Mountains & Russia \\
\hline & 62 & Saranovskii Mine, Ural Mountains & Russia \\
\hline C5704 & 88 & Blue Point Claim, Tuolumne, CA & USA \\
\hline 107315 & 89 & San Bernadino, CA & USA \\
\hline 139716 & 90 & Jackson(ville), CA & USA \\
\hline 107314 & 91 & Red Ledge Mine, CA & USA \\
\hline 123380 & 95 & Outokumpu & Finland \\
\hline \multirow[t]{13}{*}{161032} & 96 & Outokumpu & Finland \\
\hline & 16 & Roxbury, Litchfield County, CT & USA \\
\hline & 17 & Roxbury, Litchfield County, CT & USA \\
\hline & 18 & Roxbury, Litchfield County, CT & USA \\
\hline & 19 & Roxbury, Litchfield County, CT & USA \\
\hline & 22 & Diamond Lake, Glastonbury, CT & USA \\
\hline & 41 & Serrote Redondo, Pedra Lavrada, Paraiba & Brazil \\
\hline & 44 & Altay, Xinjiang & China \\
\hline & 47 & Diamond Lake, Glastonbury, CT & USA \\
\hline & 57 & Roxbury, Litchfield County, CT & USA \\
\hline & 60 & Sedalia Mine, Sadilia, Chafee County, CO & USA \\
\hline & 68 & Kievy, Kola Peninsula & Russia \\
\hline & 80 & Bella Vista Claim, Mitkof Island, SE AK & USA \\
\hline 80219-2 & 197 & Ray Mica Mine, Yancey County, NC & USA \\
\hline 118214 & 198 & Spruce Pine, NC & USA \\
\hline 17909 & 199 & Thorne Mountain, Macon County, NC & USA \\
\hline 166062 & 200 & Chestnut Flat, NC & USA \\
\hline C5278 & 201 & Hawk, NC & USA \\
\hline 90518 & 202 & Gore Mountain, NY & USA \\
\hline 107142 & 203 & Brooklyn Tunnel, NY & USA \\
\hline 132686 & 204 & Gassets, VT & USA \\
\hline $\mathrm{C} 2780$ & 220 & Schwartzenstein, Tyrol & Austria \\
\hline 143917 & 221 & Schwartzenstein, Tyrol & Austria \\
\hline C2779 & 222 & Zillertal, Tyrol & Austria \\
\hline 134685 & 223 & Ruggles Mine, $\mathrm{NH}$ & USA \\
\hline 107140 & 224 & Mink Pond, NH & USA \\
\hline 107136 & 225 & Gilsum, NH & USA \\
\hline \multicolumn{4}{|c|}{ Spessartine } \\
\hline & 30 & Fujian Province & China \\
\hline & 38 & Minas Gerais & Brazil \\
\hline & 39 & Garnet Hill, White Pine County, NV & USA \\
\hline & 40 & Little Three Mine, Ramona, San Diego County, CA & USA \\
\hline & 45 & Ely, White Pine County, NV & USA \\
\hline & 55 & Tongbei, Yunxiao, Fujian Province & China \\
\hline & 59 & Tongbei, Yunxiao, Fujian Province & China \\
\hline & 63 & Minas Gerais & Brazil \\
\hline 134521 & 157 & Ermo Mine, Minas Gerais & Brazil \\
\hline 170978 & 158 & Kaokoveld & Namibia \\
\hline 48745 & 162 & Amelia Courthouse, VA & USA \\
\hline 135296 & 163 & Rutherford, VA & USA \\
\hline 114143 & 164 & Rutherford, VA & USA \\
\hline R3448 & 165 & Allen Mica Mine, VA & USA \\
\hline 107304 & 166 & Delaware County, PA & USA \\
\hline 107304-1 & 167 & Delaware County, PA & USA \\
\hline C5331-1 & 168 & Topaz Mountains, UT & USA \\
\hline C5331-2 & 169 & Topaz Mountains, UT & USA \\
\hline
\end{tabular}




\begin{tabular}{|c|c|c|c|}
\hline \multicolumn{4}{|c|}{$\begin{array}{c}\text { Table 1. (Continued) } \\
\text { GARNET SAMPLES }\end{array}$} \\
\hline S.I. \# & Spec \# & Location & Country \\
\hline R14530 & 170 & Nathop, CO & USA \\
\hline 48559 & 171 & Nathop, CO & USA \\
\hline $\mathrm{C} 2726$ & 172 & Nathop, CO & USA \\
\hline 166829 & 209 & Ash Creek, AZ & USA \\
\hline $\mathrm{R} 16774$ & 210 & Governador Valadares, Minas Gerais & Brazil \\
\hline 106097 & 211 & Golconda mine, Minas Gerais & Brazil \\
\hline Weld-2-2 & 212 & Weld, ME & USA \\
\hline \multicolumn{4}{|l|}{ Pyrope } \\
\hline & 77 & not known & Ivory Coast \\
\hline & 81 & not known & Africa \\
\hline & 82 & not known & \\
\hline 115588 & 173 & Macon County, NC & USA \\
\hline $92684-3$ & 174 & Franklin County, NC & USA \\
\hline 133612 & 175 & Rauhammaren & Norway \\
\hline 143894 & 176 & unknown & Tanzania \\
\hline R3421 & 177 & Kimberly & South Africa \\
\hline 128290 & 178 & Kamferdam, Kimberly & South Africa \\
\hline 128285 & 179 & Barkley & South Africa \\
\hline 128282 & 180 & Monastary Mine, Kimberly & South Africa \\
\hline 162498 & 181 & Doria Maria Massif & Italy \\
\hline 122845 & 213 & Garnet Ridge, AZ & USA \\
\hline 107198 & 214 & Navajo Reservation, AZ & USA \\
\hline 83108 & 215 & Rio de Chelly, AZ & USA \\
\hline 120315 & 216 & Fort Defiance, AZ & USA \\
\hline R3418 & 217 & Trziblitz, Bohemia & Czechoslovakia \\
\hline 82575 & 218 & Bilin, Bohemia & Czechoslovakia \\
\hline 107199 & 219 & near Traborice, Bohemia & Czechoslovakia \\
\hline \multicolumn{4}{|c|}{ Mixed Pyrope-Spessartine-Grossular } \\
\hline & 83 & Umba River Valley & Tanazania/Kenya \\
\hline \multicolumn{4}{|c|}{ Mixed Spessartine-Andradite } \\
\hline & 75 & Mutumba & Madagascar \\
\hline \multicolumn{4}{|c|}{ Mixed Andradite-Pyrope } \\
\hline & 76 & Umba River Valley & Kenya \\
\hline \multicolumn{4}{|c|}{ Type Unknown } \\
\hline & 53 & Erongo & Namibia \\
\hline & 66 & Nigar Valley & Pakistan \\
\hline
\end{tabular}

\footnotetext{
${ }^{a}$ The samples come from two sources: the mineral collection of Smithsonian Institution and samples acquired specifically for this study. The samples are classified in the table by predominant end-member type based on documentary records since chemical analyses are not presently available for most samples.
}

and polished for subsequent electron microprobe chemical analysis. The LIBS system at ARL consists of a Big Sky CFR200 laser ( 70 mJ/pulse, $1064 \mathrm{~nm}, 9 \mathrm{~ns}$ pulse width) and a 7-channel LIBS2500+ spectrometer with broadband coverage from $\sim 200-960 \mathrm{~nm}$ $(\sim 0.1 \mathrm{~nm}$ resolution, $1.5 \mu \mathrm{s}$ gate delay, $1 \mathrm{~ms}$ gate width). For each sample, $3-5$ surface cleaning shots were taken in the center area of the garnet chip before sets of 25 single-laser-shot broadband LIBS emission spectra were acquired over 13,699 linearly spaced channels in a CCD spectrometer. Withinsample compositional variability was not investigated in this study.

\section{Results and Discussion}

As the six garnet types have the same $\mathrm{Si}-\mathrm{O}$ anionic structural framework and it is only six cations $(\mathrm{Ca}$, $\mathrm{Fe}, \mathrm{Al}, \mathrm{Mg}, \mathrm{Mn}$, and $\mathrm{Cr}$ ) in various paired combinations that determine the specific garnet variety, the first objective was considered achievable by single- shot LIBS. The second objective of the study is considered a much more challenging problem, and one that single-shot broadband LIBS might not be sufficiently powerful to accomplish because of withinsample compositional zoning and the expectation that spectral differences between samples from different places will be more subtle, likely depending on small differences in sample trace element concentrations that reflect both the geological domain and the fluid conditions under which a garnet formed. Considering that broadband LIBS sensitivities generally are in the tens to hundreds of parts per million (ppm), single-shot LIBS spectra may not record trace elements present in garnets at such concentrations because of low signal-to-noise considerations.

One approach to determining garnet compositional type would be to locate the specific wavelengths (Table 2 ) for the major elements indicative of each species of garnet; the relative intensities of 
Table 2. Selected Elemental and lonic Emission Lines from the Garnet LIBS Spectra (Wavelengths in Nanometers)

\begin{tabular}{|c|c|}
\hline $\mathrm{Al} \mathrm{I}$ & 394,396 \\
\hline $\mathrm{Al}$ II & 358 \\
\hline $\mathrm{Ca} \mathrm{I}$ & $422,428,429,430.2,430.7,431,442,443,445,534,558,612,643,646,714$ \\
\hline $\mathrm{Ca}$ II & $315,317,393,396,866$ \\
\hline Cr I & $358,359,360.5,425,427.5,429,520.5,520.6,521$ \\
\hline Cr II & $283.6,284.3,286$ \\
\hline $\mathrm{Fe} \mathrm{I}$ & $\begin{array}{l}248,297,302,344,347,349,356,357,360,361,363,364,371,374.5,374.9,381,382,382.5 \text {, } \\
\quad 383,384,385,406,407,427,432,438,487,489,492,495,532,537,542,544,545,561\end{array}$ \\
\hline Fe II & $234.2,234.8,238.2,238.8,239,240,241,259,261,273,274.6,274.9,275$ \\
\hline H I & 656 \\
\hline K I & 766,770 \\
\hline Li I & 670,812 \\
\hline $\mathrm{Mg} \mathrm{I}$ & $285,383,517,518$ \\
\hline $\mathrm{Mg}$ II & 279,280 \\
\hline Mn I & $353,354,403,476.2,476.6,478,482$ \\
\hline Mn II & $259,260,293.3,293.9,294$ \\
\hline $\mathrm{N} \mathrm{I}$ & $742,744,746,821,822,824,859,862,868,870,871,871.8$ \\
\hline $\mathrm{Na} \mathrm{I}$ & $568.2,568.8,615,616,818,819$ \\
\hline O I & $715,777,795,844,926$ \\
\hline Si I & $205,212,220,221,221.7,230,243.5,244,245,250,251.6,251.9,252.4,252.8,288$ \\
\hline Si II & $207,236,237,634,637$ \\
\hline
\end{tabular}

the major peaks of the broadband LIBS spectrum at these wavelengths could then be used to classify a sample. Clearly the prominent peaks in the spectra of Fig. 2 are those for the most abundant divalent and trivalent cations present, and it is these elements that define the primary chemical differences between the garnet types. For example, from visual inspection of the LIBS spectrum in Fig. 3(a), it is possible to readily identify uvarovite $\left[\mathrm{Ca}_{3} \mathrm{Cr}_{2}\left(\mathrm{SiO}_{4}\right)_{3}\right]$ on the basis of the three groups of $\mathrm{Cr}$ peaks at (i) 357.9, 359.3 , and $360.5 \mathrm{~nm}$; (ii) $425.4,427.5$, and $429.0 \mathrm{~nm}$; and (iii) $520.5,520.6$, and $520.8 \mathrm{~nm}$ [24]. We have observed that the same is true for near end-member pyrope $\left[\mathrm{Mg}_{3} \mathrm{Al}_{2}\left(\mathrm{SiO}_{4}\right)_{3}\right]$, which has a characteristic

\section{Garnet}

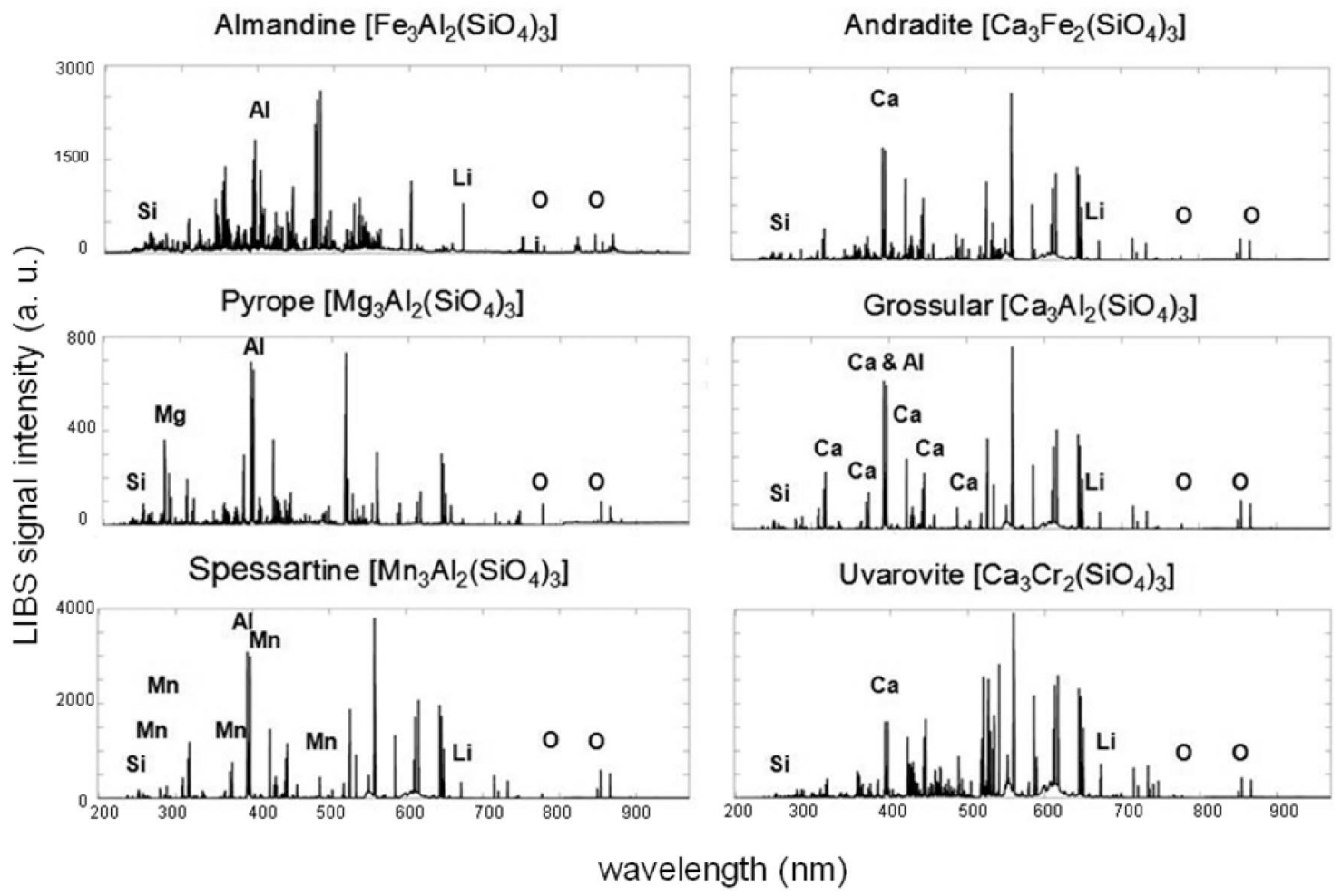

Fig. 2. Examples of broadband LIBS spectra for the six common garnet compositional types: almandine $\left[\mathrm{Fe}_{3} \mathrm{Al}_{2}\left(\mathrm{SiO}_{4}\right)_{3}\right]$, pyrope $\left[\mathrm{Mg}_{3} \mathrm{Al}_{2}\left(\mathrm{SiO}_{4}\right)_{3}\right]$, spessartine $\left[\mathrm{Mn}_{3} \mathrm{Al}_{2}\left(\mathrm{SiO}_{4}\right)_{3}\right]$, andradite $\left[\mathrm{Ca}_{3} \mathrm{Fe}_{2}\left(\mathrm{SiO}_{4}\right)_{3}\right]$, grossular $\left[\mathrm{Ca}_{3} \mathrm{Al}_{2}\left(\mathrm{SiO}_{4}\right)_{3}\right]$, and uvarovite $\left[\mathrm{Ca}_{3} \mathrm{Cr}_{2}\left(\mathrm{SiO}_{4}\right)_{3}\right]$. The clear differences observed in the broadband spectra reflect the chemical differences in the structural composition of the six garnets. 
$\mathrm{Mg}^{2+}$ emission line pair at 279.6 and $280.3 \mathrm{~nm}$ and a single $\mathrm{Mg}$ line at $518.3 \mathrm{~nm}$. However, since chemical mixing is common among the different garnet types, it is expected that most samples will contain components of other garnet types in solid solution to varying extents. For example, Fig. $3(b)$ is a LIBS spectrum for a garnet from New Hampshire, USA, exhibiting strong emission lines at 257.6, 259.4, and $260.6 \mathrm{~nm} ; 403.1,403.3$, and $403.5 \mathrm{~nm}$; and 475.4 and $482.4 \mathrm{~nm}$, indicating a spessartine, as classified, but one with a significant component of almandine present as a consequence of extensive solid solution between $\left[\mathrm{Mn}_{3} \mathrm{Al}_{2}\left(\mathrm{SiO}_{4}\right)_{3}\right]$ and $\left[\mathrm{Fe}_{3} \mathrm{Al}_{2}\left(\mathrm{SiO}_{4}\right)_{3}\right]$ components, as documented by the presence of a weaker sets of Fe emission lines at $344.1 \mathrm{~nm} ; 373.3,373.5$, and $373.3 \mathrm{~nm}$; and $433.4,495.8$, and $516.8 \mathrm{~nm}$ [24]. Such an approach to classification might be possible, but would be time consuming and problematic, so a statistical signal processing approach was investigated as an alternative that could be used in realtime analysis and classification applications.

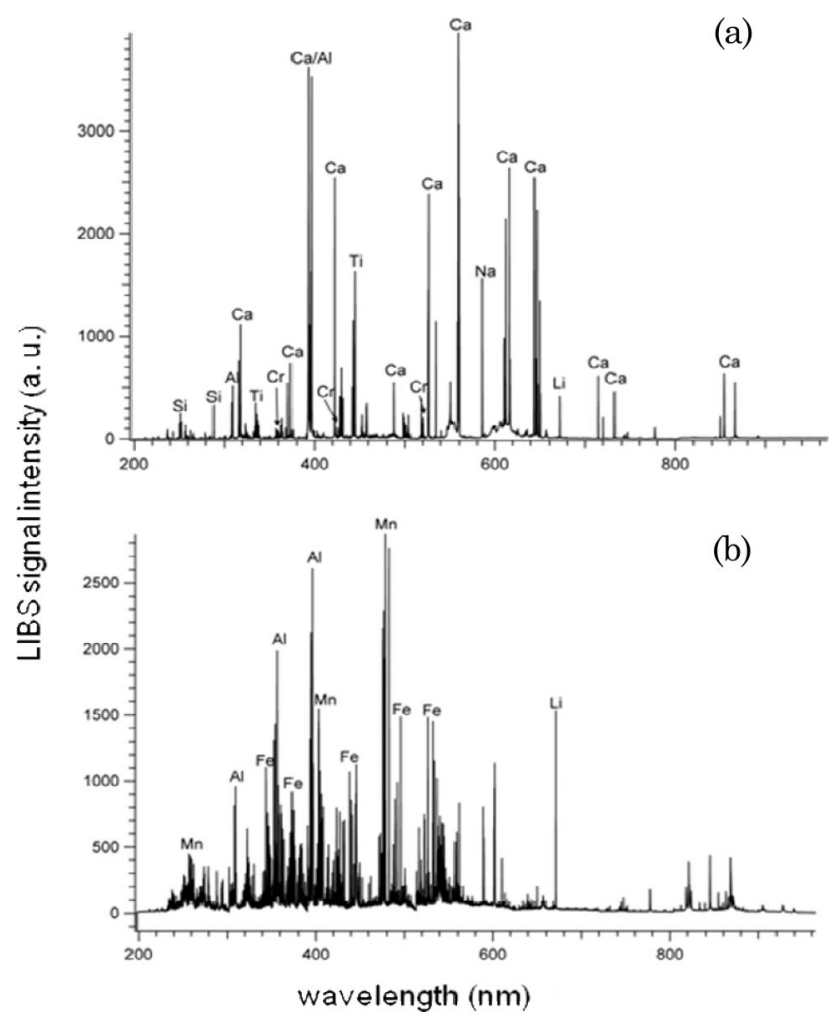

Fig. 3. Comparison of broadband LIBS spectra, with emission lines for selected elements identified, for (a) a pure end-ember uvarovite garnet $\left[\mathrm{Ca}_{3} \mathrm{Cr}_{2}\left(\mathrm{SiO}_{4}\right)_{3}\right]$ from Quebec, Canada, that shows the strong $\mathrm{Ca}$ emission lines together with the weak $\mathrm{Cr}$ and $\mathrm{Si}$ emission lines and (b) a mixed composition almandinespessartine garnet from New Hampshire, USA, characterized by extensive solid solution between $\left[\mathrm{Fe}_{3} \mathrm{Al}_{2}\left(\mathrm{SiO}_{4}\right)_{3}\right]$ and $\left[\mathrm{Mn}_{3} \mathrm{Al}_{2}\right.$ $\left(\mathrm{SiO}_{4}\right)_{3}$ ] components as indicated by strong emission lines for $\mathrm{Fe}, \mathrm{Mn}$, and $\mathrm{Al}$. Note that emission lines are present in both figures for $\mathrm{Li}$ and $\mathrm{Na}$ (elements present in the garnets in very low abundance) because LIBS has a high sensitivity for low atomic weight elements that are difficult to determine by other real-time analytical techniques.
So, the approach taken in this examination of garnet was to use 25 single-shot LIBS spectra for each sample and employ the chemometric technique of partial least squares discriminant analysis (PLSDA), since this statistical approach inherently determines the wavelengths that are important for classification. PLSDA is a pattern classification technique that allows one to project both high-dimensional input data (prediction variables) and the class labels (target variables) into lower-dimensional space, such that the correlation between the prediction variables and the target variables in the lower-dimensional space is maximized [25]. PLSDA is capable of operating on high dimensional data, such as LIBS spectra, in a computationally efficient manner. By determining a linear projection to maximize correlation, PLSDA tends to place greater weights on wavelengths that are capable of discriminating between the specified classes. PLSDA has one primary user-determined parameter, the number of lower dimensions onto which both the prediction and target variables are projected, known as the number of latent variables. The best number of latent variables can be determined by selecting the value that maximizes classification performance over a finite range.

To ensure that a classification algorithm will yield robust performance to unseen data, it is necessary to evaluate the algorithm's performance using data not considered when training the algorithm. This process, typically known as "cross validation," begins by training the classification algorithm using a subset of the data while leaving the remainder of the data to assess the algorithm's performance. This process repeats until each sample of the dataset has been left out of the training set and used to evaluate the classifier. Overall algorithm performance can then be determined by aggregating the classification performance of each sample from the case when it was excluded from the training sets.

Selecting which samples of the dataset are simultaneously excluded from the training set is critical to obtaining an accurate assessment of algorithm performance when cross validating datasets comprised of LIBS spectra. Since the LIBS database is comprised of single-shot broadband spectra from 25 laser shots for each garnet sample, the spectra derived from a particular sample should be highly correlated with one another. Thus, if spectra from individual laser shots on a particular sample were used to train the algorithm, while additional spectra from the same sample were used to evaluate algorithm performance, the performance would most likely be artificially inflated from the true performance on unseen data. Therefore, when cross validating a pattern classification algorithm on the LIBS spectra, it is important to ensure that the spectra from all of the shots for a particular sample are simultaneously excluded from the training set when they are used to evaluate performance. This is the approach used here for all performance evaluations. The classification algorithm is trained excluding all 25 of the spectra for 
a particular garnet sample and the performance is evaluated using these 25 excluded shots. This process is repeated for each of the garnet samples. Although multiple spectra are collected for each garnet sample, the classification algorithm is designed to determine the class (type or geographic location) of each garnet sample. Therefore, a decision should be made on a sample rather than each laser shot. In order to reach a single decision for each sample, a voting procedure is used to combine the algorithm output for each laser shot. Then, the most common class decision obtained is assigned as the determined class for the garnet sample.

\section{A. Garnet Composition Classification}

Principal components analysis (PCA) was used to visualize the LIBS spectral database in two dimensions. PCA is a standard technique for dimensionality reduction that finds a linear mapping from a high-dimensional space to a lower-dimensional space without the use of class labels [26]. The linear mapping is chosen to maximize the variance in the resulting lower-dimensional space and is determined by performing an eigen-decomposition on the covariance matrix of the observation dimensions. Although PCA was not used in this study to classify LIBS spectra, it provided a helpful means of visualizing the LIBS database within the context of the classification task of interest.

Figure 4 displays the projection of the LIBS spectral database onto the first two principal components (PCs) with the gray symbols denoting the pyralspite group and the black symbols denoting the ugrandite group. The six different symbols indicate the six garnet compositional types. For visual clarity, the PCs were calculated using all available LIBS spectra, and the mean of the spectra from the 25 laser shots for each sample was calculated and then projected

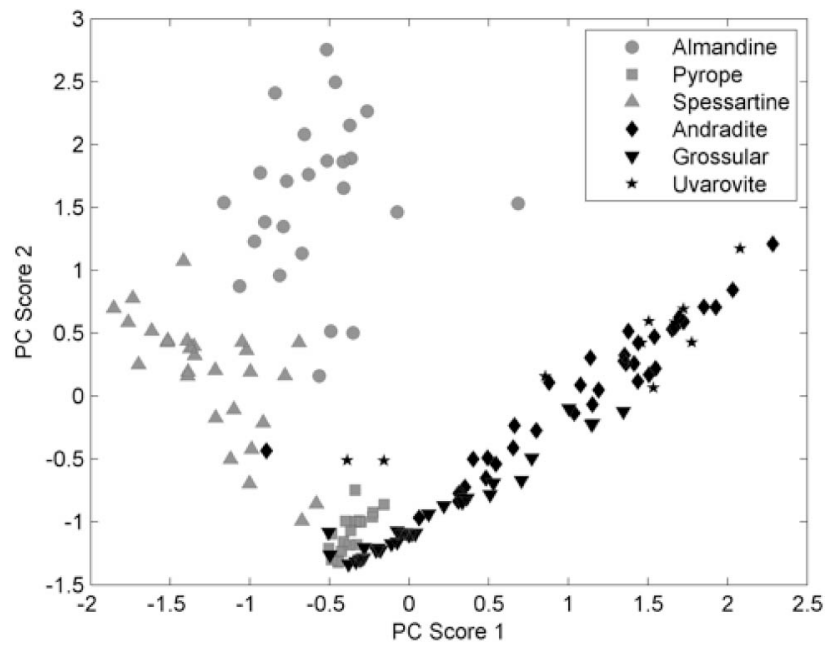

Fig. 4. Principal components projection of the LIBS spectra database with samples labeled by garnet compositional group and type. Gray symbols denote pyralspite: circles = almandine, upright triangles $=$ spessartine, $\quad$ and $\quad$ squares $=$ pyrope . Black symbols denote ugrandite: diamonds = andradite, inverted triangles $=$ grossular, and stars = uvarovite. into the two-dimensional space. Therefore, each point in Fig. 4 corresponds to an individual garnet sample in the database. It can be seen that both the major garnet groups and the garnet compositional types cluster in a distinct manner in the two-dimensional PC projection, which indicates that robust performance for the classification task should be obtainable using most pattern classification techniques.

The two group arrays in Fig. $\underline{4}$ converge to the same origin on this plot as a consequence of their common Si-O anionic structural framework. The ugrandite group of andradite $(\mathrm{Ca}+\mathrm{Fe})$, grossular $(\mathrm{Ca}+\mathrm{Al})$, and uvarovite $(\mathrm{Ca}+\mathrm{Cr})$ garnets define the coherent array of positive slope on the right side of the diagram with partly overlapping groupings of data points because they have $\mathrm{Ca}$ as a common " $\mathrm{A}$ "site constituent. By contrast, the pyralspite group of almandine $(\mathrm{Fe}+\mathrm{Al})$, spessartine $(\mathrm{Mn}+\mathrm{Al})$, and pyrope $(\mathrm{Mg}+\mathrm{Al})$ garnets form a broad and less coherent array on the left side of the figure with largely separated groupings of data points, reflecting the extensive solid solution possible within the three garnet types of this group. Clearly, the solitary andradite point in Fig. 4 that falls in the midst of the spessartine array is the result of a misclassification of that sample.

The best number of latent variables for the PLSDA classifier was estimated by performing the crossvalidated performance evaluation using a number of latent variables ranging from 1 to 30 . The highest percent of correct classifications was obtained when using 26 latent variables, and the results shown in Fig. 4 were obtained with this number of latent variables. Figure 5 shows the percent of correct of garnet type classifications as a function of the number of latent variables. Classification performance first plateaus at $>85 \%$ at just five variables and then reaches a second plateau of $\sim 90 \%$ correct classification using 13 variables, before reaching maximum classification performance of just under $95 \%$ at 26 variables.

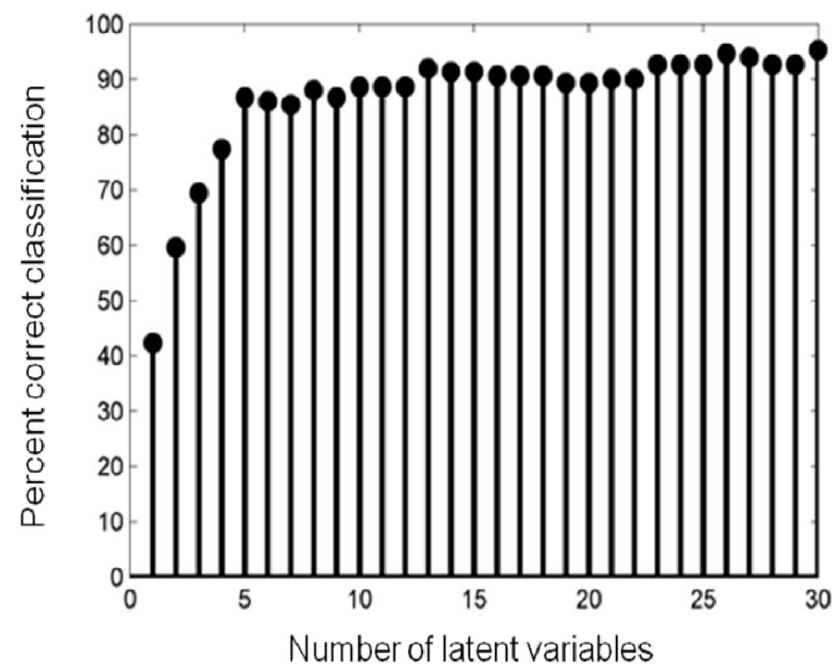

Fig. 5. Garnet minor species classification performance as a function of the number of latent variables of a PLSDA classifier. 
An algorithm to determine the garnet compositional type was constructed using the PLSDA method, and the performance was quantified using the cross validation and voting procedures described above. This process produced the classification "confusion matrix" shown in Fig. 6. The cells of the columns of the Fig. 6 matrix denotes the percentage of garnet samples that were identified as belonging to a class (i.e., compositional type) when the samples actually belong to the class designated by the row. The numbers to the right of each row of the confusion matrix indicate the number of samples of each class that were used to evaluate the algorithm. For example, all 18 of the pyrope samples were so assigned, whereas 26 of 28 spessartines were classified correctly but 2 of these samples were instead classified as andradite.

From Figs. $\underline{5}$ and $\underline{6}$, it is seen that the garnet type classification success is high, determined correctly for $94.7 \%$ of the tested samples. If this same classification algorithm is used to indentify the major garnet group, ugrandite or pyralspite, then a $98 \%$ correct identification rate is obtained. It is important to note that the primary misclassification error is to assign other garnet types to the grossular $(\mathrm{Ca}+\mathrm{Al})$ class: 2 of 28 spessartines $(\mathrm{Mn}+\mathrm{Al}), 3$ of 37 andradites $(\mathrm{Ca}+\mathrm{Fe})$, and 1 of 10 uvarovites $(\mathrm{Ca}+\mathrm{Cr})$. These six misclassifications are likely a consequence of the fact that both $\mathrm{Ca}$ and $\mathrm{Al}$ have strong emission lines that are very pronounced features of the garnet LIBS spectra. Since Ca is present in all three ugrandite group garnets as a major constituent, its abundant presence in andradite and uvarovite turns out, in some cases, to dominate the much weaker $\mathrm{Fe}$ and $\mathrm{Cr}$ emission lines with the PLSDA classifier even though $\mathrm{Al}$ is absent in the LIBS spectra. For the pyralspite group, $100 \%$ classification success is achieved for almandine and pyrope, the two garnet

\begin{tabular}{|c|c|c|c|c|c|c|c|c|}
\hline & $A L$ & 100 & 0 & 0 & 0 & 0 & 0 & [26] \\
\hline$\stackrel{ \pm}{0}$ & PY & 0 & 100 & 0 & 0 & 0 & 0 & [18] \\
\hline & SP & 0 & 0 & 92.86 & 0 & 7.14 & 0 & [28] \\
\hline 응 & AN & 0 & 0 & 2.7 & 89.19 & 8.11 & 0 & [37] \\
\hline 童 & GR & 0 & 0 & 0 & 3.12 & 96.88 & 0 & [32] \\
\hline 호 & UV & 0 & 0 & 0 & 0 & 10 & 90 & [10] \\
\hline & & AL & PY & SP & AN & GR & UV & \\
\hline
\end{tabular}

Fig. 6. Classification confusion matrix for the PLSDA classifier trained to identify minor species. Each entry in the matrix indicates the percentage of samples that were identified as the column class when they are actually of the row class. Legend: $\mathrm{Al}=$ almandine $\left[\mathrm{Fe}_{3} \mathrm{Al}_{2}\left(\mathrm{SiO}_{4}\right)_{3}\right], \quad \mathrm{PY}=$ pyrope $\left[\mathrm{Mg}_{3} \mathrm{Al}_{2}\left(\mathrm{SiO}_{4}\right)_{3}\right], \quad \mathrm{SP}=$ spessartine $\left[\mathrm{Mn}_{3} \mathrm{Al}_{2}\left(\mathrm{SiO}_{4}\right)_{3}\right], \mathrm{AN}=$ andradite $\left[\mathrm{Ca}_{3} \mathrm{Fe}_{2}\left(\mathrm{SiO}_{4}\right)_{3}\right], \mathrm{GR}$ $=$ grossular $\left[\mathrm{Ca}_{3} \mathrm{Al}_{2}\left(\mathrm{SiO}_{4}\right)_{3}\right]$, and $\mathrm{UV}=$ uvarovite $\left[\mathrm{Ca}_{3} \mathrm{Cr}_{2}\left(\mathrm{SiO}_{4}\right)_{3}\right]$. Percent classification success $=94.7 \%$. types lacking $\mathrm{Ca}$. As both contain $\mathrm{Al}$, the presence of $\mathrm{Fe}$ and $\mathrm{Mg}$ peaks in these garnet compositions drive the classification. By contrast, since the presence of even a small amount of $\mathrm{Ca}$ in solid solution will dominate a garnet LIBS spectrum and Mn is a weak emission line in the garnet LIBS spectra and thus contributes less robustly to the classification, it is presumed that a small amount of $\mathrm{Ca}$ in some spessartine samples is the cause of their $\sim 7 \%$ misclassification rate.

In addition to classifying the garnet samples on the basis of composition using a statistical approach like PLSDA, one can examine the degree similarity amongst the garnet samples using a distance matrix approach [27], which illustrates the similarities between each pair of samples in the database. Figure 7 is a distance matrix derived from the LIBS spectra for the 157 samples assigned to one of the six garnet types. Darker colors correspond to samples that are compositionally similar, whereas lighter colors correspond to samples that are dissimilar in composition. The distance between a pair of samples is determined using all 25 LIBS spectra from each of the two samples by calculating the average euclidean distance between each pair of 25 laser shots. Therefore, the distance between a sample and itself is typically nonzero. Calculating the distance matrix in this way includes a measure of the shot-to-shot variability for a single sample.

As seen from Fig. 7, the six garnet types form dark blocks lying along the principal diagonal, with each sample most similar to itself, as expected. In some cases, most samples of a garnet type are broadly similar in character (dark shading), whereas in others there is a large degree of heterogeniety (mixed dark and light shadings) within a garnet type. For exam-

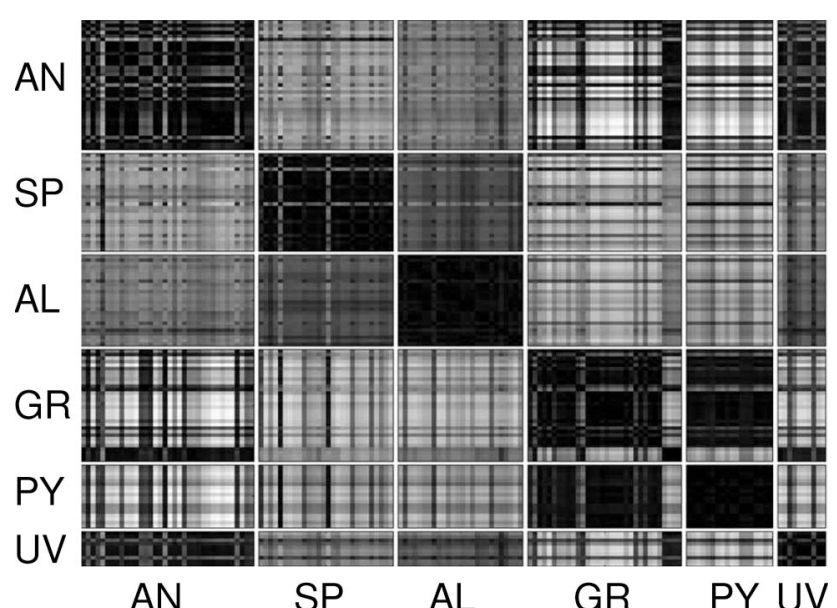

Fig. 7. Total distance matrix for the 157 garnet samples analyzed in this study (37 andradites-A, 28 spessartines-SP, 26 almandines-AL, 32 grossulars-GR, 19 pyropes-PY, and 10 uvarovites-UV). The white rows and columns denote the boundaries between each of the six garnet types. The dark to light shading for each block in the diagram illustrates the comparative compositional similarity $($ dark $=$ similar, light $=$ dissimilar $)$ among the samples of a row or column to the sample lying on the principal diagonal of the diagram. 
ple, compare the pyrope and almandine groups in Fig. 7 to the andradite and grossular groups. Given that chemical analyses are not presently available for all samples and the samples were assigned to one of the six garnet types based on accompanying documentation, for which a type assignment may have been based on color, samples that are striking dissimlar to others of its type may in fact be misclassified or may be solid solution mixtures (e.g., the last four samples of the $\mathrm{Ca}-\mathrm{Al}$ grossular group, which bear a stronger similarity to that group). Similarly, some of the samples of the Ca-Al grossular group have a strong similarty to the $\mathrm{Mg}$-Al pyrope group, which may denote $\mathrm{Mg}$ substitution for $\mathrm{Ca}$ in some samples of the grossular group.

\section{B. Garnet Location Identification}

Identification of the geographic location of a garnet sample is a much more difficult task than the classification of garnet by major group or compositional type, since the indicative characteristics of the spectra are likely to result from a subtle difference in trace element character as a consequence of fluidcrust interaction at the time of garnet formation rather than differences in the primary chemistry of the samples. To create an algorithm that can effectively identify the location of origin, analysis was performed assuming that the type of garnet is known. In practice, one could reasonably consider first identifying the type of garnet, as described above, followed by a determination of its place of origin. The performance of identification of geographic location de- scribed below does not consider the error rates observed in the previous section, however, complete assessment of system performance would need to consider the accuracy of both stages of classification.

For this portion of the study, it was necessary to use only a subset of 87 of the 157 garnet samples because multiple samples from a locality were required for the cross-validation training procedure. The assignment of garnets into geographic groups was based on the large-scale similarity in host geological setting. For the pyralspite group, (i) the $\mathrm{Fe}-\mathrm{Al}$ garnet almandine set consisted of samples from the Tyrolian Alps of Austria (3), western Connecticut, USA (7), western North Carolina, USA (5), and New Hampshire, USA (3); (ii) the Mg-Al garnet pyrope set consisted of samples from South Africa (4), Czech Republic (3), and Arizona, USA (4); and (iii) the Mn$\mathrm{Al}$ garnet spessartine, the set consisted of samples from the Broken Hill, Australia (3), Minas Gerias, Brazil (5), the Fujian Province of China (3), Nathop, Colorado, USA (3), and central Virginia, USA (4). For the ugrandite group, (i) the $\mathrm{Ca}-\mathrm{Fe}$ andradite garnet set consisted of samples from the Alps of western Italy (5), Franklin, New Jersey, USA (4), and the Zermatt area of the Swiss Alps (5); (ii) the Ca-Al grossular garnet set consisted of samples from California, USA (3), Coahuila, Mexico (5), Shipton Township, Canada (7), and the Siberia area of Russia (4); and (iii) the $\mathrm{Ca}-\mathrm{Cr}$ uvarovite garnet set consisted of samples from California, USA (4) and the Ural Mountains of Russia (3). The cross-validation and voting procedures described above were again used
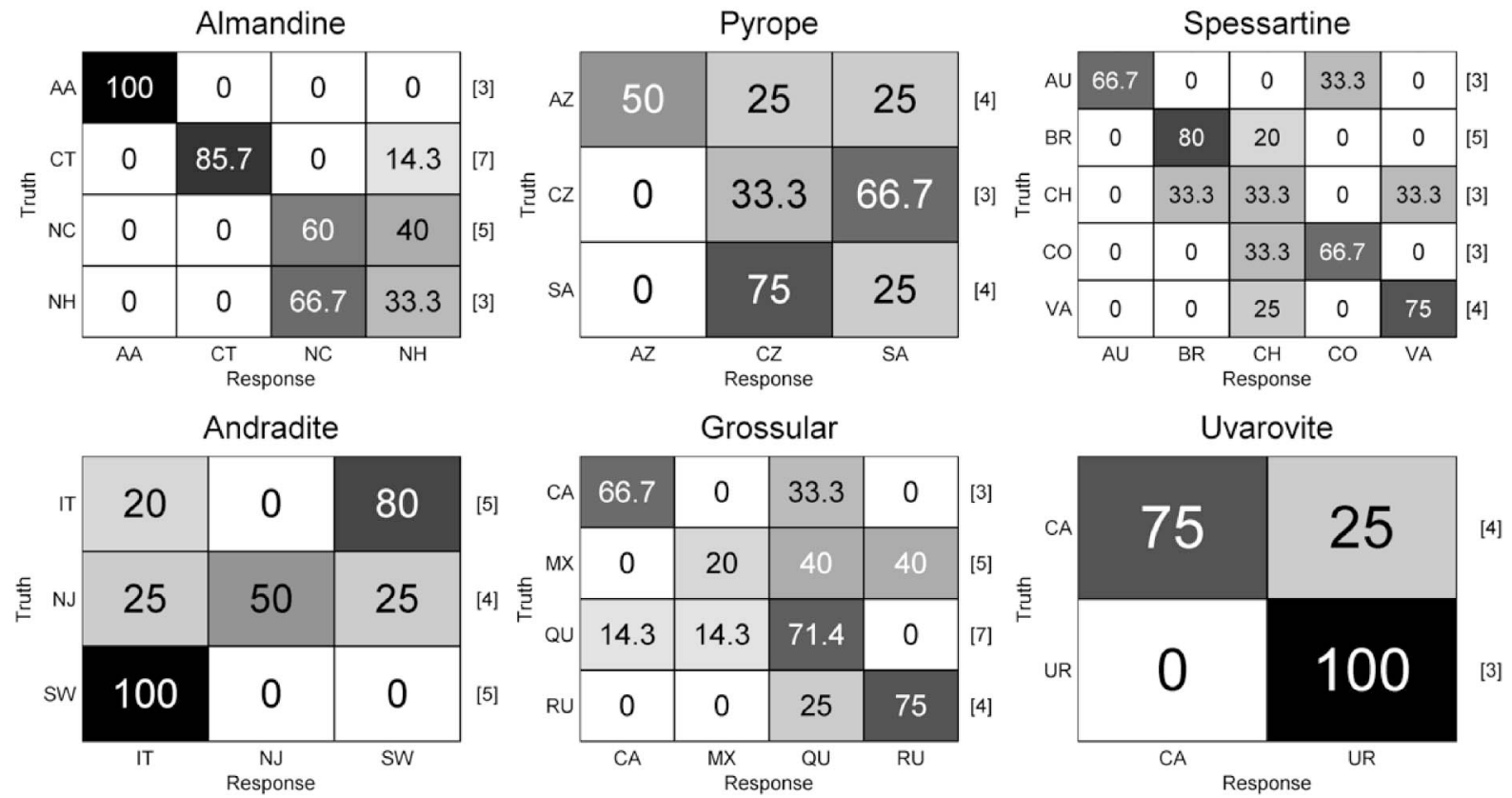

Fig. 8. Classification confusion matrices for the PLSDA classifier applied to locations for each garnet type consisting of three or more samples. The two-letter abbreviation along the left side and bottom of each matrix denote the geographic location $(\mathrm{AA}=\mathrm{Austria}$, $\mathrm{CT}=$ Connecticut,$\quad \mathrm{NC}=$ North Carolina,$\quad \mathrm{NH}=$ New Hampshire,$\quad \mathrm{AZ}=$ Arizona,$\quad \mathrm{CZ}=$ the Czech Republic,$\quad \mathrm{SA}=\mathrm{South}$ Africa, $\mathrm{AU}=$ Australia,$\quad \mathrm{BR}=$ Brazil,$\quad \mathrm{CH}=$ China,$\quad \mathrm{CO}=$ Colorado, $\mathrm{VA}=$ Virginia,$\quad \mathrm{IT}=$ Italy,$\quad \mathrm{NJ}=\mathrm{New}$ Jersey,$\quad \mathrm{SW}=\mathrm{Switzerland}$, $\mathrm{CA}=$ California, $\mathrm{MX}=$ Mexico, $\mathrm{QU}=$ Quebec, $\mathrm{RU}=$ Siberia, Russia, and UR = Ural Mountains, Russia). Additional details of location are given in the text. The numbers in brackets along the right side of each matrix indicated the number of samples analyzed from each locality of that matrix row. 
to assess classification performance for place determination within each of the garnet types. When using the cross-validation procedure, issues may arise for small sample sets since there would be only very limited training data locations of one or two samples when one sample is withheld for evaluation. Therefore, as noted above, the only locations for which there were more than three samples were used in the geographic analysis.

The PLSDA algorithm was applied to the LIBS spectral datasets for the geographic groups for each of the six garnet types, and classification performance was quantified as before. The resulting confusion matrices for location identification for each garnet type are shown in Fig. 8. These confusion matrices are similar in form to that shown in Fig. 6 . As anticipated, the identification of the place of origin is a more difficult task than the identification of garnet compositional type. The overall success in classifying the subset of 87 garnets is only $55 \%$, with classification performance for individual garnet types ranging from $21.4-85.7 \%$ (Fig. 9). Not surprisingly, classification performance is best for those locations represented by the largest number of samples. The very poor result for the andradite group results from the assignment of the samples from the Swiss Alps to the Italian Alps group and vice versa. This indicates that these garnets are derived from the same geological domain and should be so grouped, which would elevate the andradite classification success rate to $85.6 \%$ and the overall performance to an encouraging level of $69 \%$.

Figure 10 presents the distance matrices for each garnet type for geographic groups having three or more samples. Ideally, one would see strong within-place similarity for each garnet type and dissimilarity with other places. The almandine distance matrix is the most exemplary in this regard, but one of the North Carolina samples is clearly different

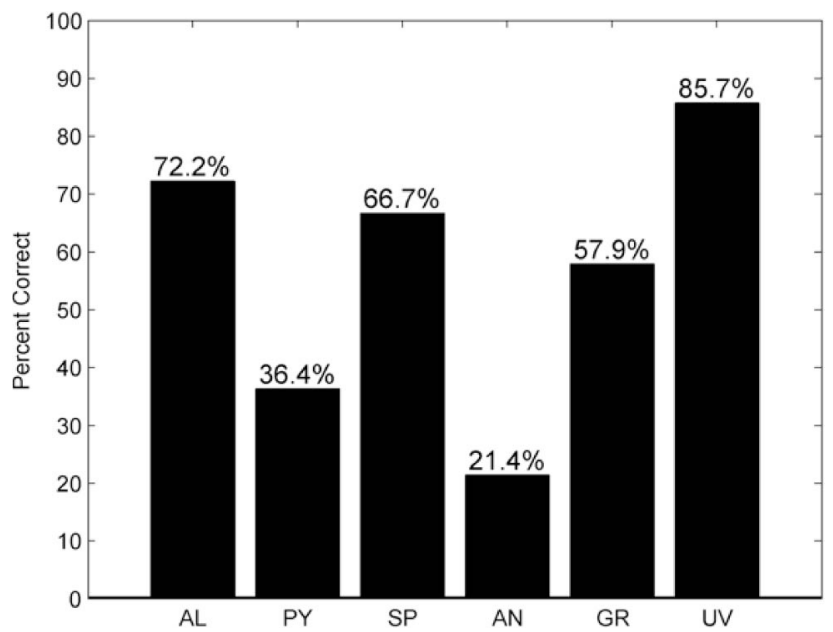

Fig. 9. Classification of garnets of different type by geographic origin. Legend: $\mathrm{AL}=$ almandine $\left[\mathrm{Fe}_{3} \mathrm{Al}_{2}\left(\mathrm{SiO}_{4}\right)_{3}\right], \quad \mathrm{PY}=$ pyrope $\left[\mathrm{Mg}_{3} \mathrm{Al}_{2}\left(\mathrm{SiO}_{4}\right)_{3}\right], \quad \mathrm{SP}=$ spessartine $\left[\mathrm{Mn}_{3} \mathrm{Al}_{2}\left(\mathrm{SiO}_{4}\right)_{3}\right], \quad \mathrm{AN}=$ andradite $\left[\mathrm{Ca}_{3} \mathrm{Fe}_{2}\left(\mathrm{SiO}_{4}\right)_{3}\right], \mathrm{GR}=\operatorname{grossular}\left[\mathrm{Ca}_{3} \mathrm{Al}_{2}\left(\mathrm{SiO}_{4}\right)_{3}\right]$, and $\mathrm{UV}=$ uvarovite $\left[\mathrm{Ca}_{3} \mathrm{Cr}_{2}\left(\mathrm{SiO}_{4}\right)_{3}\right]$.
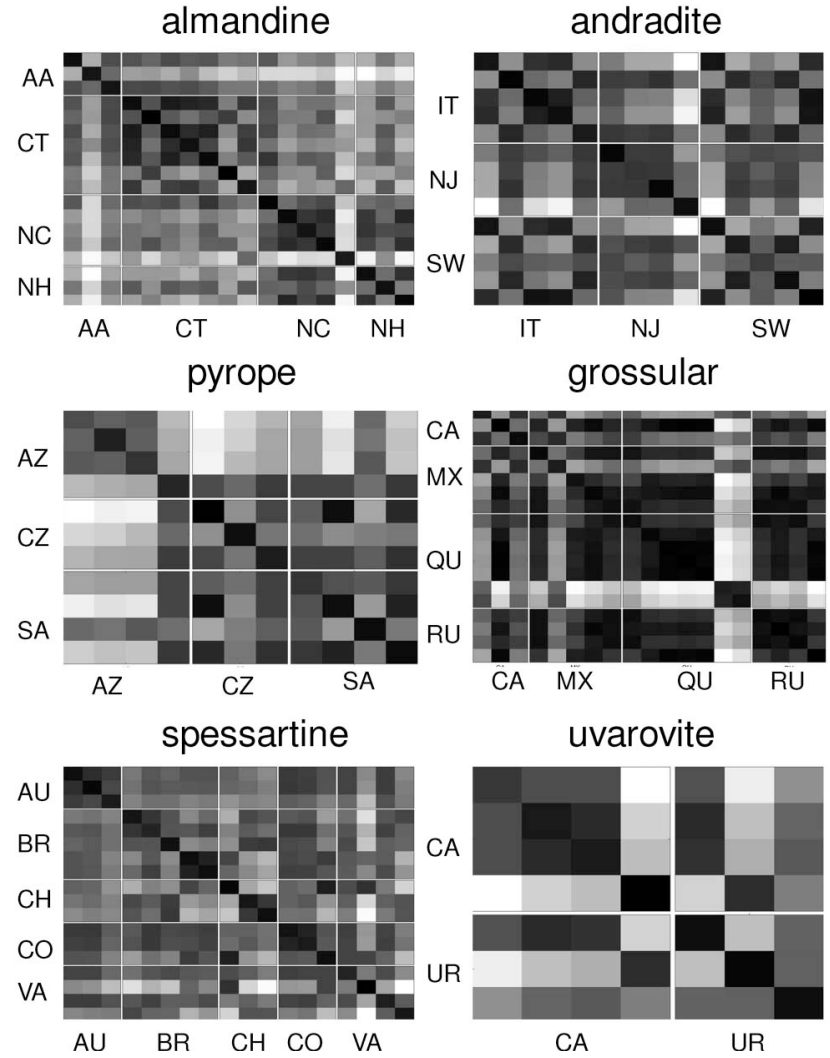

Fig. 10. Total distance matrix for the six different garnet types for geographic locations with three or more samples. The white rows and columns denote the boundaries between each of the six garnet types. Legend: for almandine, $\mathrm{AA}=$ Austria, $\mathrm{CT}=$ Connecticut, $\mathrm{NC}=$ North Carolina, and $\mathrm{NH}=$ New Hampshire; for pyrope, $\mathrm{AZ}=$ Arizona,$\quad \mathrm{CZ}=$ Czech Republic,$\quad$ and $\mathrm{SA}=$ South Africa; for spessartine, $\mathrm{AU}=$ Australia, $\mathrm{BR}=$ Brazil, $\mathrm{CH}=$ China, $\mathrm{CO}=$ Colorado,$\quad \mathrm{VA}=$ Virginia; $\quad$ for andradite,$\quad \mathrm{IT}=$ Italy, $\mathrm{NJ}=\mathrm{New}$ Jersey, and $\mathrm{SW}=$ Switzerland; for grossular $\mathrm{CA}=$ California, $\mathrm{MX}=$ Mexico, $\mathrm{QU}=$ Quebec, and RU = Russia; for uvarovite, $\mathrm{CA}=$ California and $\mathrm{UR}=$ Ural Mountains.

compositionally than the other four. The same is observed for the grossulars, where one Quebec and one Russian sample again are compositionally distinct and for the uvarovites, where one of the California samples is unlike the other three.

To gain some insight into why place of origin classification is significantly more difficult than classification on the basis of bulk composition, it is useful to examine the physical relation between the learned parameters of the PLSDA classifier and the known chemistry difference between the garnet samples. For a classification problem that uses PLSDA, the importance of each wavelength to the classification algorithm can be measure by using variable importance in the projection (VIP) scores [28]. Larger VIP scores indicate a greater importance to classification. Figure 11 plots the VIP scores for selected wavelengths labeled according to the elements corresponding to these wavelengths. The VIP scores for the PLSDA model for composition classification are shown with hatched bars, while the average VIP scores for the geographic classifications are 


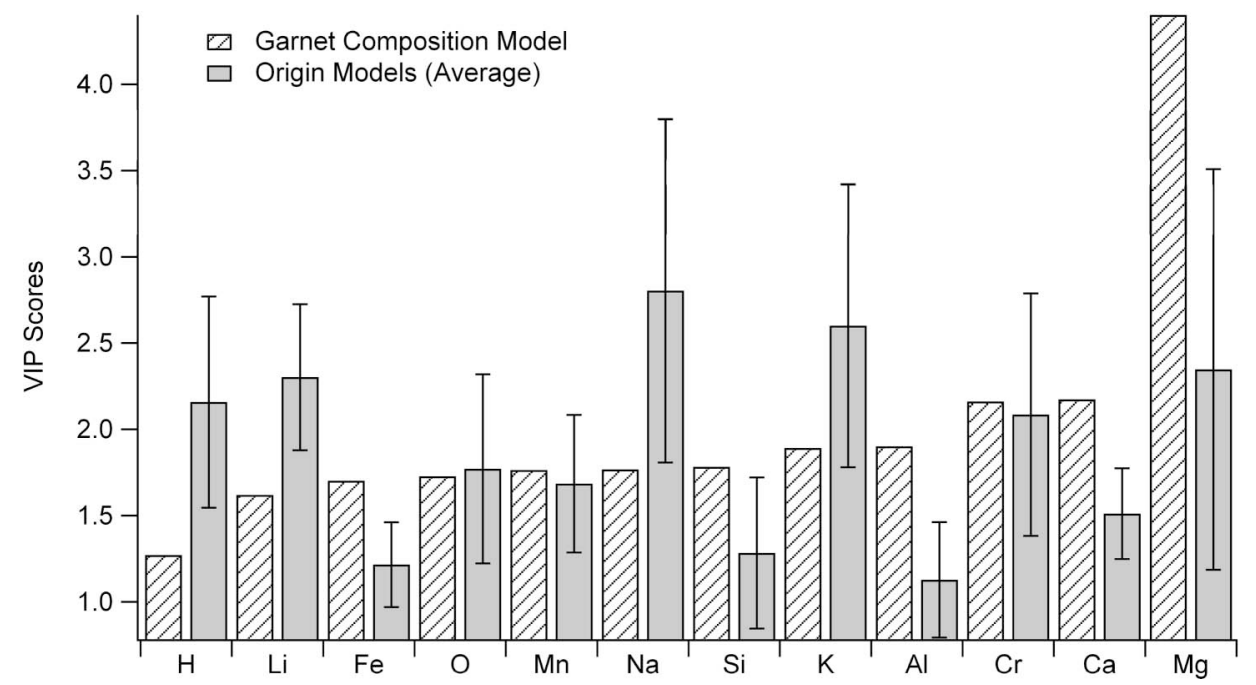

Fig. 11. VIP scores for PLSDA models at selected wavelengths (Table 2). VIP scores for the garnet composition model are shown in hatched pattern and the average VIP scores for the six location of origin classification models are shown in solid pattern for the 12 elements most important for garnet classification with LIBS. Error bars indicate two standard deviations.

shown in solid bars with error bars indicating two standard deviations. It can be seen in Table 2 that the wavelengths most important to garnet composition classification correspond to the main cations that differentiate the species of garnets $(\mathrm{Ca}, \mathrm{Mg}$, $\mathrm{Al}, \mathrm{Fe}, \mathrm{Mn}, \mathrm{Cr}$ ), whereas the wavelengths important to locational classification correspond to impurities $(\mathrm{Na}, \mathrm{K}, \mathrm{Li}, \mathrm{H})$ within the garnets. The dependency of location classification on impurities within the samples indicates why discerning location is a significantly more difficult task than classification of garnet by compositional type. To characterize the changes in impurities as a function of location, a significant number of garnet samples must be included in the library from which the geographic models are constructed. For the current analysis, there were only a limited number of samples of a particular garnet type from a particular location. A larger LIBS spectra database with more samples of each species from each location should enable more accurate and robust locality identification. This conclusion is supported by the distance matrices for the garnets used in this portion of the study.

\section{Summary}

Garnet, a common mineral in many metamorphic and igneous rocks, occurs in six common compositional species. In this study, statistical signal processing and classification techniques have been applied to broadband LIBS spectra acquired by laser-induced breakdown spectroscopy for a suite of 157 garnets of different composition from 92 locations worldwide. Each broadband LIBS spectrum comprises measured plasma light intensities between 200 and $960 \mathrm{~nm}$. A set of 25 LIBS spectra was acquired for each garnet sample, and partial least squares discriminant analysis was used to classify garnet samples based on composition and geographic origin. Careful consideration was given to the cross-validation procedure to ensure that the classification algorithm is robust to unseen data. Partial least squares discriminant analysis (PLSDA) was applied to the LIBS spectral database to develop and quantify the performance of pattern classification algorithms that, in the future, could be used in the context of a spectral library to determine both type and geographic location of an unknown garnet sample. The best number of latent variables for the the PLSDA classifier was estimated by performing the cross-validated performance evaluation using a number of latent variables ranging from 1 to 30 . Classification performance was observed to plateau at $>85 \%$ at just five variables, reach a second plateau of $\sim 90 \%$ correct classification using 13 variables, and reach a maximum of $94.7 \%$ at 26 variables. A $98 \%$ correct identification rate is obtained for identification of the major garnet groups, ugrandite or pyralspite, using the same classification algorithm. A subset of 87 of the 157 garnets from locations having more than three samples was used to test whether the location of origin of the garnets could be determined. Overall success in geographic classification was only $55 \%$, with classification performance for individual garnet types ranging from $21.4-85.7 \%$, with classification performance best for those locations represented by the largest number of samples. The very poor result for the andradite group results from the assignment of the samples from the Swiss Alps to the Italian Alps group and vice versa. This indicates that these garnets are derived from the same geological domain and should be so grouped, which would elevate the andradite classification success rate to $85.6 \%$ and the overall performance to an encouraging level of $69 \%$. An analysis of VIP scores shows that the LIBS spectral wavelengths most important to garnet composition classification correspond to the main cations that differentiate the species of garnets $(\mathrm{Ca}$, $\mathrm{Mg}, \mathrm{Al}, \mathrm{Fe}, \mathrm{Mn}, \mathrm{Cr}$ ), whereas the wavelengths important to locational classification correspond to impurities $(\mathrm{Na}, \mathrm{K}, \mathrm{Li}, \mathrm{H})$ within the garnets. These 
results suggest that broadband LIBS analysis can be used to classify garnets of different composition and has the potential to discriminate garnets of different geographic origin. The accumulation of a larger number of LIBS spectra than used in this study (e.g., 100) would address the signal-to-noise issue and likely provide a more robust classification performance.

The analytical work reported here was undertaken by senior author D. Alvey as part of a U.S. Military Academy cadet summer research project with the US Army Research Laboratory (ARL), supported by the Argonne National Laboratory undergraduate student summer program. The signal processing and classification work was conducted in the SPACISS laboratory at Duke University. Additional support was provided by an ARL Fellow stipend to R. Harmon.

\section{References}

1. R. S. Harmon, F. C. DeLucia Jr., A. W. Miziolek, K. L. McNesby, R. A. Walters, and P. D. French, "Laser-induced breakdown spectroscopy (LIBS) - an emerging field-portable sensor technology for real-time, in situ geochemical and environmental analysis," Geochem. Explor. Environ. Anal. 5, 21-28 (2005).

2. R. S. Harmon, F. C. DeLucia Jr., C. E. McManus, N. J. McMillan, T. F. Jenkins, M. E. Walsh, and A. W. Miziolek, "Laser-induced breakdown spectroscopy-an emerging chemical sensor technology for field-portable, real-time geochemical, mineralogical, and environmental applications," Appl. Geochem. 21, 730-747 (2005).

3. R. S. Harmon, J. Remus, N. J. McMillan, C. McManus, L. Collins, and J. L. Gottfried, "LIBS analysis of geomaterials: geochemical fingerprinting for the rapid analysis and discrimination of minerals," Appl. Geochem. 24, 1125-1141 (2008).

4. N. J. McMillan, C. E. McManus, R. S. Harmon, F. C. DeLucia Jr., and A. W. Miziolek, "Laser-induced breakdown spectroscopy analysis of complex silicate minerals-Beryl," Anal. Bioanal. Chem. 385, 263-271 (2006).

5. N. J. McMillan, R. S. Harmon, F. C. De Lucia Jr., and A. W. Miziolek, "Laser-induced breakdown spectroscopy analysis of minerals-carbonates and silicates," Spectrochim. Acta Part B 62, 1578-1536 (2007).

6. C. E. McManus, N. J. McMillan, R. S. Harmon, R. C. Whitmore, F. C. DeLucia Jr., and A. W. Miziolek, "The use of laser induced breakdown spectroscopy (LIBS) in the determination of gem provenance-Beryls," Appl. Opt. 47, G72-G79 (2008).

7. J. L. Gottfried, R. S. Harmon, F. C. De Lucia Jr., and A. W. Miziolek, "Multivariate analysis of LIBS spectra for geomaterial classification," Spectrochim. Acta Part B 64, 1009-1019 (2009).

8. W. A. Deer, R. A. Howie, and J. Zussman, Rock-Forming Minerals, Volume 1. Ortho- and Ring Silicates (Longman Press, 1975).

9. W. E. Ford, "A study of the relations existing between the chemical, optical, and other physical properties of the members of the garnet group," Am. J. Sci. 40, 33-49 (1919).
10. M. J. Fleisher, "The relation between chemical composition and physical properties in the garnet group," Am. Mineral. 22, 751-758 (1937).

11. C. S. Hurlbut and C. Klein, Manual of Mineralogy (Wiley, 1977).

12. J. W. Anthony, R. A. Bideaux, K. W. Bladh, and M. C. Nichols, Handbook of Mineralogy (Mineralogical Society of America, 2001); http://www.handbookofmineralogy.org/pdfs/Pyrope .PDF, http://www.handbookofmineralogy.org/Almandine.PDF, http://www.handbookofmineralogy.org/Andradite.PDF, http:// www.handbookofmineralogy.org/Grossular.PDF, http://www. handbookofmineralogy.org/Spessartine.PDF, http://www. handbookofmineralogy.org/Uvarovite.PDF.

13. J. Ganguly and J. C. Kennedy, "The energetics of natural garnet solid solution," Contrib. Mineral. Petrol. 48, 137-148 (1974).

14. R. J. Tracy, P. Robinson, and A. B. Thompson, "Garnet composition and zoning in the determination of temperature and pressure of metamorphism, central Massachusetts," Am. Mineral. 61, 762-775 (1976).

15. J. Ito and C. Frondel, "Synthesis of the grossularite-spessartite series," Am. Mineral. 53, 1036-1038 (1968).

16. J. Ito and C. Frondel, "Stilpnomelane and spessartitegrossularite from Franklin, New Jersey," Am. Mineral. 50, 498-501 (1965).

17. R. J. Tracy, P. Robinson, and A. B. Thompson, "Garnet composition and zoning in the determination of temperature and pressure of metamorphism, central Massachusetts," Am. Mineral. 61, 762-775 (1976).

18. T. P. Loomis, "Reaction of zoning of garnet," Contrib. Mineral. Petrol. 52, 285-305 (1975).

19. W. H. Blackburn, "Zoned and unzoned garnets from the Grenville gneisses around Gananoque, Ontario," Canad. Mineral 9, 691-698 (1969).

20. D. Smith and F. R. Boyd, "Compositional zonation in garnets in peridotite xenoliths," Contrib. Mineral Petrol. 112, 134147 (1992).

21. B. M. Loeffler and R. G. Burns, "Shedding light on the color of gems and minerals," Am. Scientist 64, 636-647 (1976).

22. K. Nassau, "The origin of color in minerals," Am. Mineral. 63, 219-229 (1978)

23. G. R. Rossman, "The California Institute of Technology Mineral Spectroscopy Database" (California Institute of Technology, 2009); http://minerals.gps.caltech.edu/FILES/Visible/garnet/ index.htm.

24. Y. Ralchenko, A. E. Kramida, J. Reader, and NIST ASD Team, NIST Atomic Spectra Database (version 3.1.5) (National Institute of Standards and Technology, 2008); available online, http://physics.nist.gov/asd3.

25. S. Wold, M. Sjöström, and L. Eriksson, "PLS-regression: a basic tool of chemometrics," Chemometr. Intel. Lab. Syst. 58, 109-130 (2001).

26. C. M. Bishop, Pattern Recognition and Machine Learning (Springer, 2007).

27. J. E. Gentle, Matrix Algebra: Theory, Computations, and Applications in Statistics (Springer, 2007).

28. I.-G. Chong and C.-H. Jun, "Performance of some variable selection methods when multicollinearity is present," Chemometr. Intel. Lab. Syst. 78, 103-112 (2005). 